\title{
蹎势の池湧水群を中心とした浅層地下水の揮発性有機盐素化合物の濃度比*
}

\author{
宮崎礼子** . 小倉紀雄 $* * *$
}

\section{The Concentration ratio of the Volatile Organochlorine Compounds in the Masugatanoike Springs and Shallow Groundwater}

\author{
Reiko Miyazaki**, Norio Ogura***
}

\begin{abstract}
Water qualities of spring waters (NOk, NOe, NOw, and NOm) at Kokubunji City, Tokyo which springs were very closed were studied during January to December 1990. N0e and N0w are belong to Masugatanoike springs. These springs were very close and their water qualities such as anions or metals were similar.

In these spring waters we detected volatile organochlorine compounds (VOCC) such as trichloroethylene (TCE), tetrachloroethylene (PCE), and 1-1-1trichloroethane (MC). Although sampling stations were very close, VOCC concentrations of each spring waters showed different tendency. At NOk and NOe, TCE concentraiotn was highest of three compounds. But at NOw and NOm, PCE concentration was highest of all.

Concentrations of TCE and MC had close relations at these springs. And these relations were different between $\mathrm{NOk}-\mathrm{N} 0 \mathrm{e}$ and $\mathrm{NOw}-\mathrm{N} 0 \mathrm{~m}$. At the result, it was suggested that there were the relations with TCE concentrations and MC concentrations and there ware two groundwater flows.

キーワード：揮発性有機塩素化合物、浅層地下水、地下水流れ、濃度比、真姿の池湧水群 Volatile Organochlorine Compounds, Shallow Groundwater, Concentration ratio, Masugatanoike Springs
\end{abstract}

* 本研究は東京農工大学農学部の卒業研究として行ったものである

** 大成建設(株)技術研究所 Technology Research Center, Taisei Corporation

***東京農工大学農学部 Faculty of Agriculture, Tokyo University of Agriculture and Technology 


\section{1. はじめに}

武蔵野台地の武蔵野面と立川面とを分ける国分 寺崖線は東京都立川市付近から発し多摩川まで 至っており、崖線沿いには昔から湧水が多く湧出 している。そのうちの多くは、宅地造成、下水道 の完備などによる地下水の減少により水量が減少 したり、枯渴しているが、国分寺市、小金井市だ けでも日立中央研究所構内、真姿の池湧水群、東 京経済大学構内湧泉などに比較的水量の多い湧水 が残っている。著者らの研究室では、国分寺崖線 沿いの湧水のうち国分寺市の真姿の池湧水群を中 心として湧水の水質測定を定期的に行ってきた。 環境庁選定の名水百選に選ばれている真姿の池湧 水群は多摩川の支流の野川の水源の 1 つで、付近 に東屋や遊歩道などが整備されており、市民の憩 の場としても親しまれている。ここから検出され る污染物質は、以前は硝酸イオン、塩化物イオン を中心とする家庭排水由来または農業由来の污染 物質が主であったが、最近では半導体工業、クリー ニング業などから排出される揮発性有機塩素化合 物が認められるようになった(加藤、小倉、1991)。 さらに、真姿の池湧水群において肉眼で認められ る 2 つ大きな湧出口では揮発性有機塩素化合物 による污染状況が異なる傾向が認められた(平野、 1991)。このことから、真姿の池湧水群には異な る地下水流が流れ込んでいる可能性が考えられ た。そこで、本研究は東京都国分寺市の真姿の池 湧水群を中心とした小集水域における揮発性有機 塩素化合物濃度を測定し、地下水流れとの関係を 考察することを目的として行った。

\section{2. 調查地概要}

武蔵野台地は東京の西部に広がっており、洪積 世の後半に作られた日本で最大級の沖積台地であ る。この台地は北は荒川、南は多摩川、西は山地 と丘陵に囲まれており、台地の等高線は関東山地 東麓の青梅付近を扇頂として東に広がる扇形をし ている。この扇形は荒川低地帯の沈降運動により 北東方向への勾配が強く(貝塚、1957)、その傾向 は $200 \mathrm{~m}$ 以上深部の地層構造にも見られる。武蔵 野台地にはいくつかの段丘面があり、高位から金
子台、所沢台などの末吉面、豊島台や荏原台など の武蔵野面、立川面、青柳面、拝島面及びそれ以 下の断片的な段丘崖の順になっている。このうち 武蔵野面では地表から順に関東ローム層、武蔵野 碟層が堆積し、その下に帯水層である上総層群が 広がっている。武蔵野面と立川面との境に位置す る国分寺崖線は東京都立川市の JR 立川駅付近か ら発し世田谷区の二子玉川付近まで続いている。 本研究の調査地はこの崖線沿いの国分寺市に位置 する 4 地点の湧水を中心に設定した。調査を行っ た地域では武蔵野面と立川面との標高差が約 $14 \mathrm{~m}$ であった。

\section{3、試料採取地及び調查、分析方法}

\section{1 調查、採水地点}

( 1 ) 湧水

平野(1991)により真姿の池湧水群において $2 つ$ の大きな湧出口が確認されているため、本研究で はこの湧水群の 2 つの湧出口からそれぞれ別々に 試料を採取することとし、東側の湧出口を NOe、 西側の湧出口を N0w とした(図 1 )。さらに真姿 の池湧水群の東西に位置する湧水 2 地点、 N0k お よび $\mathrm{N} 0 \mathrm{~m}$ からも採取を行った(図 1 )。湧水試料 の採取および調査は1991年 1 月から12月にかけて 月 1 回又は 2 回行った。

\section{（2)浅層地下水}

崖線上の武蔵野面における地下水水質および地 下水の流れを明らかにするため、調查対象とした 湧水に比較的近い地域に扔いて浅層地下水の採水 を行った。調査は国分寺市の管理する浅井戸 1 地 点、個人所有の浅井戸 1 地点、水位観測孔 5 地点 及び共用井戸跡 7 地点の計 14 地点で行った(図 1 )。浅井戸、水位観測孔および共用井戸跡はい ずれも深度が10～ $20 \mathrm{~m}$ であることから、調査を 行った湧水と同じ带水層の地下水であるとみなし た。

\section{2 調查、試料採取および分析方法}

(1) 湧出水量

真姿の池湧水群では各湧出口毎に湧出水量を測 定することが困難であったため、NOe と NOw の 


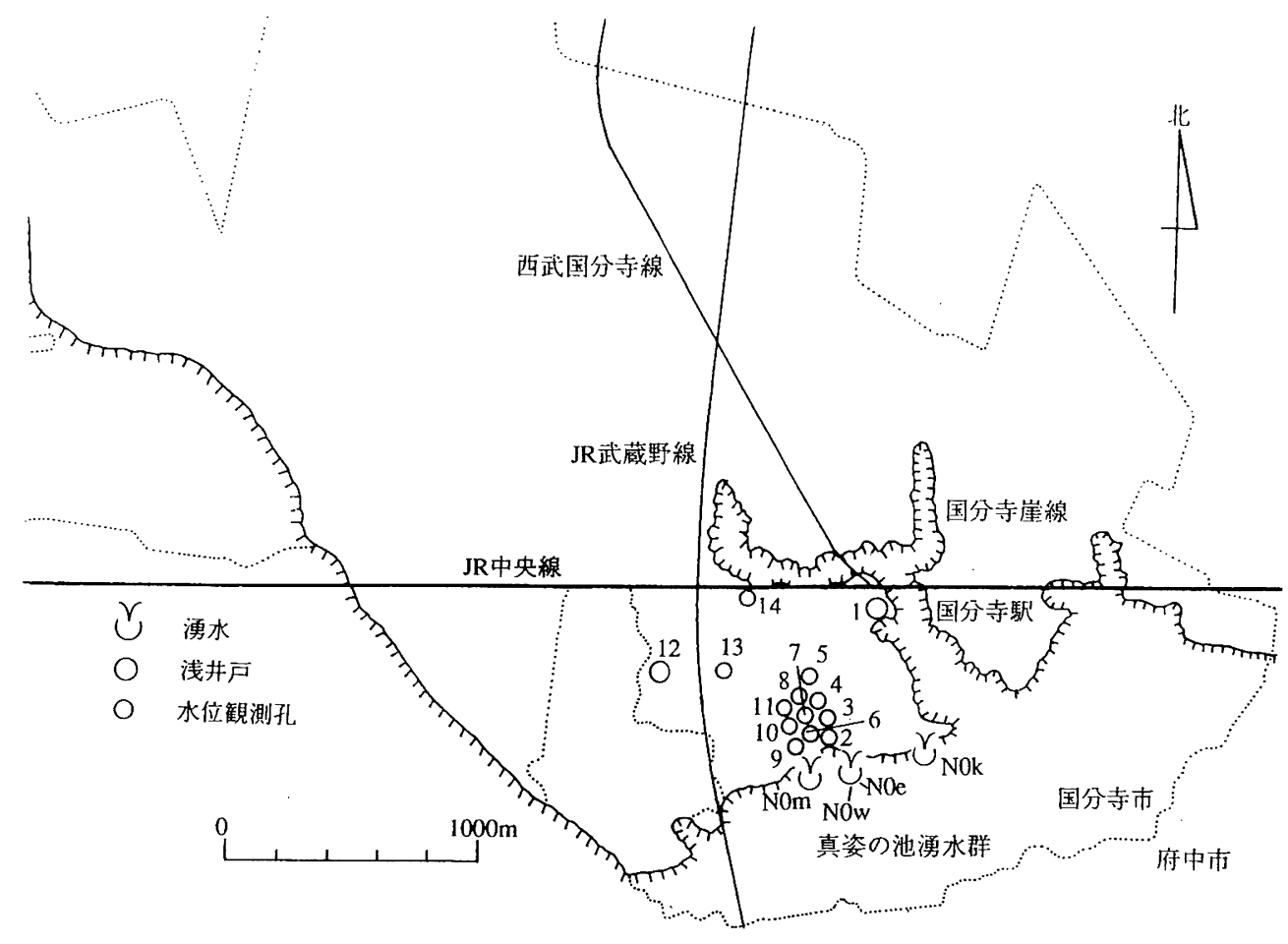

図 1 調查地点 (Sampling station)

合量を測定した。測定には、容量既知の容器に流 水を満たし、それに要した時間から湧出水量を算 出する一定容量法を用いた。 NOk、NOm について は湧出水量を測定することができなかった。

\section{(2) 一般水質項目}

採水地点において水温 $(\mathrm{Tw})$ 、電気伝導度 $(\mathrm{EC})$ を電気水質計(東邦電探 EST-3型)またはポケッ 卜伝導度計(横河北辰電気 SC51)を用いて測定 した。

その他の項目については全て調査地点で試料を 採水し、研究室に持ち帰り分析を行った。

$\mathrm{pH}$ は $\mathrm{pH}$ メータ (電気化学計器 デジタル $\mathrm{pH}$ 計 $\mathrm{HG}-3$ )、全炭酸 ( T-CO2) は赤外吸光光度計(島 津製作所 URA-106)にて測定した。溶存酸素 (DO)はウインクラー法のアジ化ナトリウム変法 に基づいて定量した。塩化物イオン $\left(\mathrm{Cl}^{-}\right)$、硝酸 イオン $\left(\mathrm{NO}_{3}{ }^{-}\right)$、硫酸イオン $\left(\mathrm{SO}_{4}{ }^{2-}\right)$ はイオンク ロマトグラフ (横河電気 IC-200)を用いて定量

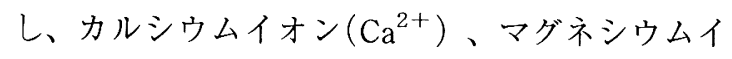

オン $\left(\mathrm{Mg}^{2+}\right)$ は原子吸光光度計(島津製作所フ レーム分光光度計 $\mathrm{AA}-670)$ にて定量を行った。 珪酸態珪素 $\left(\mathrm{SiO}_{2}-\mathrm{Si}\right)$ はモリブデン青法により定 量を行った。

\section{( 3 )揮発性有機塩素化合物}

揮発性有機塩素化合物は調査当時に水質污濁防 止法で暫定基準值(現在の環境基準值)の設定され ていた1-1-1トリクロロエタン (MC)、トリクロロ

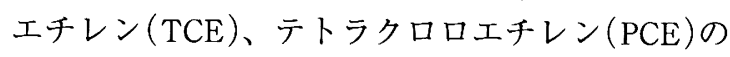
3 種類について分析を行った。

試料は採水地点で $250 \mathrm{ml}$ の共栓付ガラスビンに 取り、気泡が入らないように栓をしてシーロン フィルムで密封し、実験室に持ち帰った。実験室 において試料 $40 \mathrm{ml}$ から $\mathrm{n}$-ヘキサン $10 \mathrm{ml}$ に揮発性 有機塩素化合物を抽出した。この $\mathrm{n}$ ーヘキサンを $\mathrm{ECD}$ 付ガスクロマトグラフ（横河電気 HP5890A) に注入し、3 種類の化合物の定量分析 を行った。回収率はMC94.0\%、TCE96.6\%、 PCE99.2\%であり、5 回の分析の変動係数は 
MC2.11\%、TCE2.73\%、PCE1.83\%であった。

\section{(4)降水量}

降水量は真姿の池湧水群から南東約 $1 \mathrm{Km}$ に位 置する気象庁の気象観測所 (府中市幸町3-5-8東京 農工大学農学部構内)の1991年の值を用いた(気象 庁、1991)。

\section{4. 結果及び考察}

\section{1 湧水中の一般的な水質の概況}

調査を行った湧水 4 地点の水質の年間最大值、 最小值および年平均值を表1に示した。

4 つの湧水はいずれも 1 年を通して水温が $16^{\circ} \mathrm{C}$ 弱、 $\mathrm{pH}$ 前後、 $\mathrm{DO}$ は平均 $7.85 \sim 8.35 \mathrm{mgO}_{2} / 1$ と好 気的条件であり、 $\mathrm{SO}_{4}{ }^{2-} 、 \mathrm{Ca}^{2+} 、 \mathrm{Mg}^{2+} 、 \mathrm{SiO}_{2}-\mathrm{Si}$ などにも大きな変化は認められず、湧水間での違 いも認められなかった。

$\mathrm{NO}_{3}{ }^{-}$は $\mathrm{N} 0 \mathrm{~m}$ において 11 月に水道水基準 (10mgN/1)を超える $10.4 \mathrm{mgN} / 1$ が測定されたが、 年間の平均ではどの湧水も基準值以下であった。 また、真姿の池湧水群では既存の研究と比較して、 $\mathrm{NO}_{3}{ }^{-} 、 \mathrm{Cl}^{-}$濃度の年平均は減少傾向にあった(平 野、1992)。

\section{2 湧水中の揮発性有機塩素化合物濃度}

(1)湧水中の揮発性有機塩素化合物濃度の 月変化

調査を行った 4 地点では、揮発性有機塩素化合 物のうち調査対象とした MC、TCE、PCEの 3 種 類全てが検出されたが、基準值の $\mathrm{MC}-0.1 \mathrm{mg} / 1$ 、 $\mathrm{TCE}-0.03 \mathrm{mg} / 1 、 \mathrm{PCE}-0.01 \mathrm{mg} / 1$ を越える湧水は なかった。しかし、表 1 中の一般水質項目の場合 と異なり、濃度およびその月変化に湧水間で差が 認められた(表 1 、図 $2-\mathrm{a} \sim \mathrm{d}$ )。

調査を行った湧水の東端に位置している Nok では 3 種類の化合物の中でTCE 濃度が年間を通 して最も高かった(図 $2-\mathrm{a}$ )。年間の平均濃度は $12.2 \mu \mathrm{g} / 1$ で、他の 3 地点の平均值の 3 倍以上に 相当した。TCE 濃度は10月に急に減少し、11月 に最低值を示した後再び増加を始めたが、MC、 PCE 濃度には大きな月変化は認められなかった。

真姿の池湧水群の東側の湧出口である NOe で
は図 $2-\mathrm{b}$ に見られるように 9 月までは NOk と同 様に TCE 濃度が最も高かった。TCE 濃度は月間 降水量が $200 \mathrm{~mm}$ を超えた 8 月から減少を始め、 月間降水量が $100 \mathrm{~mm}$ 以下になった 11 月から再び 増加を始めた。PCE 濃度は 8 月に入っても減少 は認められなかったが、TCE濃度が大きく減少 したために両化合物の濃度の逆転が見られ、調査 を行っていた期間中は PCE 濃度の方が高いまま であった。 MC 濃度には大きな変化は認められな かった。

N0e から僅か $1 \mathrm{~m}$ 程西にある NOw では PCE 濃 度が最も高く、9月に入り減少を始め、11月から 増加する傾向にあった。TCE 濃度は NOk、NOe と 比較して非常に低く、10月から11月半ばにかけて 検出限界以下となった。 $\mathrm{MC}$ 濃度は年間を通して 濃度が低く変化も小さかった $($ 図 $2-\mathrm{c})$ 。

調査地点の西端の $\mathrm{N} 0 \mathrm{~m}$ では $\mathrm{N} 0 \mathrm{w}$ と同様、 $\mathrm{PCE}$ 濃度が最も高くなっていた。PCE 濃度の月変化 は N0w と類似しているが、 N0wに比べて全体的 に濃度が低かった。MC、TCEは年間を通して低 濃度であった(図 $2-\mathrm{d}$ )。

以上の結果から、4つの湧水は TCE 濃度が高 い湧水 $(\mathrm{N} 0 \mathrm{k} 、 \mathrm{~N} 0 \mathrm{e})$ と $\mathrm{PCE}$ 濃度が高い湧水 $(\mathrm{N} 0 \mathrm{w}$ 、 $\mathrm{N} 0 \mathrm{~m})$ の 2 つの゙ループに分類された。このこと より、4つの湧水が非常に近接しているにもかか わらず、異なる地下水の流れにより涵養されてい る可能性が示唆された。

\section{( 2 )揮発性有機塩素化合物濃度の湧水間で の関連性}

揮発性有機塩素化合物による污染は単独の化合 物による污染よりも、複数の化合物による複合污 染が多く(国立環境研究所、1991)、MC は TCE の代替物質として使用されているため 2 種類の化 合物の用途は類似している(Rivett et al、1990)。 また、調査を行った真姿の池湧水群においては、 加藤、小倉 $(1990) に よ り \mathrm{MC}$ 濃度と TCE 濃度と の相関が高いことが報告されている。そこで本研 究の調查地域における 3 種類の化合物間の濃度関 係を調べた結果、TCEと MC との間には正の相 関が認められた。また1991年のデー夕のみでは情 報が少ないため、著者等の研究室において1987、 1988、1990年に行われた真姿の池湧水群の水質調 
表 1 涌水の水質

(Water quality of spring waters)

\begin{tabular}{|c|c|c|c|c|c|c|c|c|c|}
\hline \multirow[b]{2}{*}{ Tw } & \multirow[b]{2}{*}{$\left({ }^{\circ} \mathrm{C}\right)$} & \multicolumn{2}{|c|}{ NOK } & \multicolumn{2}{|c|}{$\mathrm{NOe}$} & \multicolumn{2}{|c|}{ NOw } & \multicolumn{2}{|c|}{ NOm } \\
\hline & & $16.0-16.4$ & (16.2) & $15.6-16.3$ & $(15.9)$ & $15.3-16.5$ & $(15.7)$ & $15.1-15.9$ & (15.7) \\
\hline $\mathrm{EC}$ & $(\mu \mathrm{S} / \mathrm{cm})$ & 150-198 & (170) & $149-210$ & (175) & $127-206$ & (177) & $160-208$ & (184) \\
\hline $\mathrm{pH}$ & & $6.0-6.3$ & (6.1) & 5.9-6.2 & (6.0) & $6.1-6.2$ & (6.1) & 6.0-6.2 & (6.1) \\
\hline DO & $\left(\mathrm{mgO}_{2} / \mathrm{l}\right)$ & $7.08-9.56$ & $(7.85)$ & $7.35-9.17$ & $(8.11)$ & 7.82-8.94 & $(8.35)$ & $7.53-8.92$ & (8.10) \\
\hline $\mathrm{T}-\mathrm{CO}_{2}$ & $(\mathrm{mgC} / \mathrm{l})$ & $19.2-26.6$ & $(23.4)$ & $16.4-25.4$ & $(22.5)$ & $16.6-26.6$ & $(21.0)$ & $19.8-28.3$ & (23.2) \\
\hline $\mathrm{Cl}^{-}$ & $(\mathrm{mg} / \mathrm{l})$ & $10.2-18.7$ & $(13.8)$ & 8.8-15.4 & (13.1) & $11.9-14.2$ & (13.2) & 12.1-15.2 & (13.8) \\
\hline $\mathrm{NO}_{3}{ }^{\circ}$ & $(\mathrm{mg} / \mathrm{l})$ & $21.0-32.1$ & $(24.0)$ & $16.5-33.1$ & $(26.9)$ & $29.8-40.7$ & (34.4) & $26.4-46.1$ & (35.4) \\
\hline $\mathrm{NO}_{3}-\mathrm{N}$ & $(\mathrm{mgN} / \mathrm{l})$ & $4.75-5.83$ & $(5.43)$ & $5.47-7.48$ & $(6.08)$ & $6.73-8.31$ & $(7.76)$ & $5.97-10.4$ & $(8.00)$ \\
\hline $\mathrm{SO}_{4}{ }^{2}$ & $(\mathrm{mg} / \mathrm{l})$ & $6.26-9.03$ & (7.53) & $4.29-10.7$ & $(8.94)$ & 4.91-8.61 & (7.39) & $4.38-8.68$ & (7.32) \\
\hline $\mathrm{Ca}^{2+}$ & $(\mathrm{mg} / \mathrm{l})$ & $11.7-14.6$ & $(13.2)$ & $11.7-14.7$ & (12.9) & 11.6-14.4 & $(13.1)$ & $12.4-14.7$ & (12.9) \\
\hline $\mathrm{Mg}^{2+}$ & $(\mathrm{mg} / \mathrm{l})$ & $6.59-9.62$ & (8.36) & $6.24-9.55$ & (7.88) & 6.09-9.75 & $(7.99)$ & $6.48-9.85$ & $(8.22)$ \\
\hline $\mathrm{SiO}_{2}-\mathrm{Si}$ & $(\mathrm{mg} / \mathrm{l})$ & $10.5-12.6$ & (11.5) & $10.1-12.3$ & (11.3) & $10.2-14.4$ & (12.3) & $11.7-13.7$ & $(12.3)$ \\
\hline $\mathrm{MC}$ & $(\mu \mathrm{g} / \mathrm{l})$ & $0.88-2.33$ & $(1.60)$ & $0.23-0.87$ & $(0.64)$ & $0.20-0.42$ & $(0.33)$ & $0.12-0.66$ & $(0.27)$ \\
\hline TCE & $(\mu \mathrm{g} / \mathrm{l})$ & 6.84-16.07 & $(12.21)$ & $0.48-6.46$ & $(3.09)$ & N.D. -0.48 & $(0.31)$ & $0.19-1.05$ & $(0.65)$ \\
\hline $\mathrm{PCE}$ & $(\mu \mathrm{g} / \mathrm{l})$ & $0.79-1.22$ & $(0.96)$ & $1.32-1.89$ & (1.56) & 3.29-6.53 & (5.51) & $1.79-4.15$ & (3.38) \\
\hline
\end{tabular}

(a)
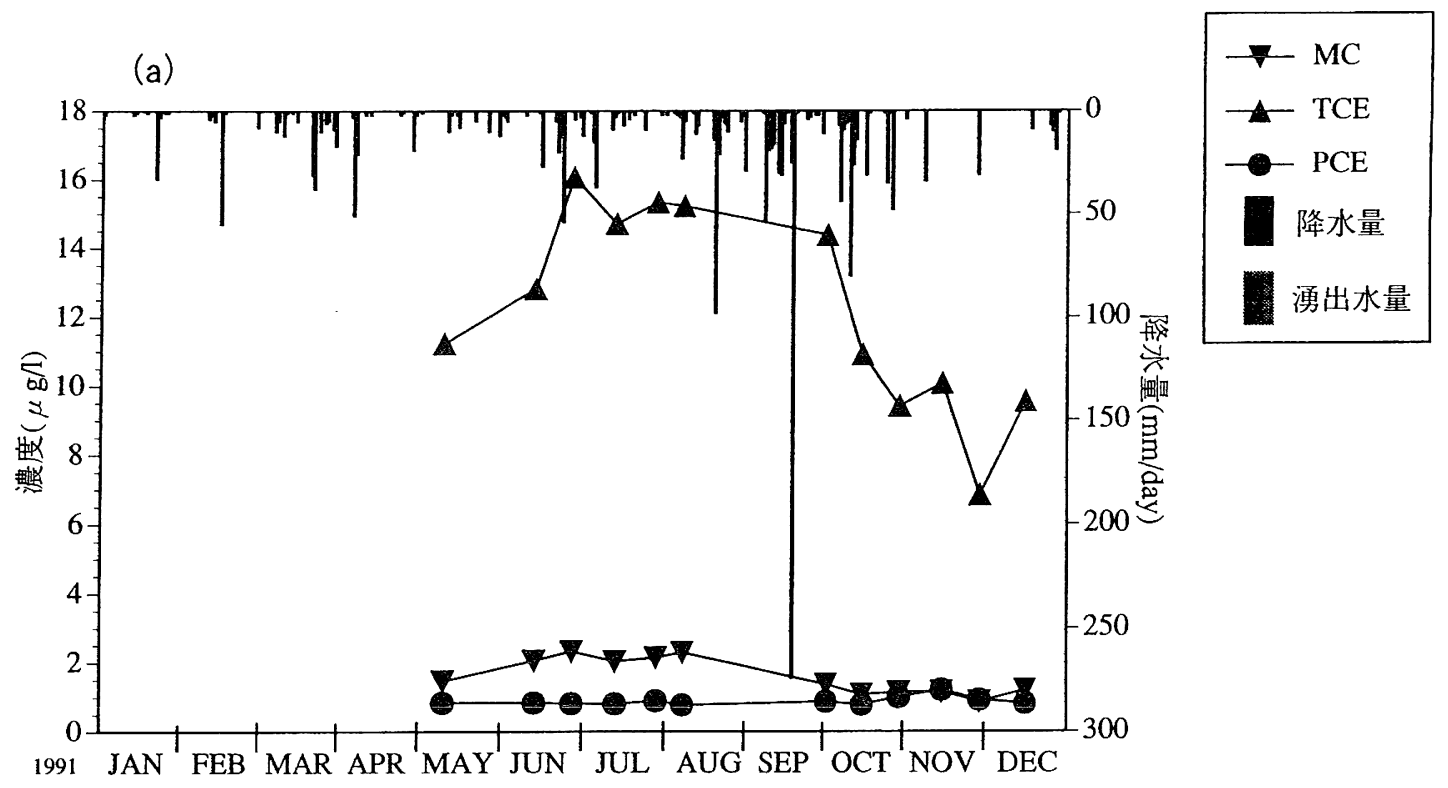

图 2 湧水の揮発性有機塩素化合物の月变化

(Monthly change of Volatile Organochlorine Compounds in spring waters)
(a) NOK
(b) $\mathrm{NOe}$
(c) $\mathrm{NOW}$
(d) $\mathrm{NOm}$ 
(b)

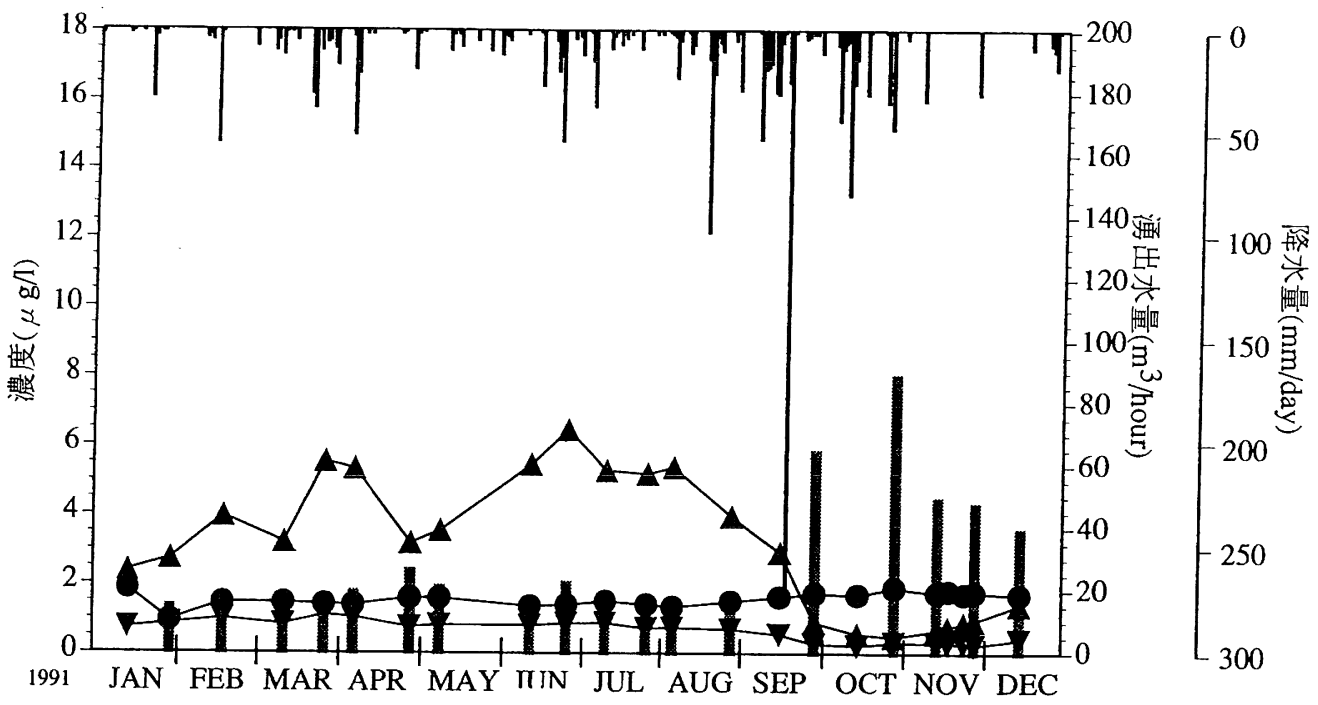

(c)

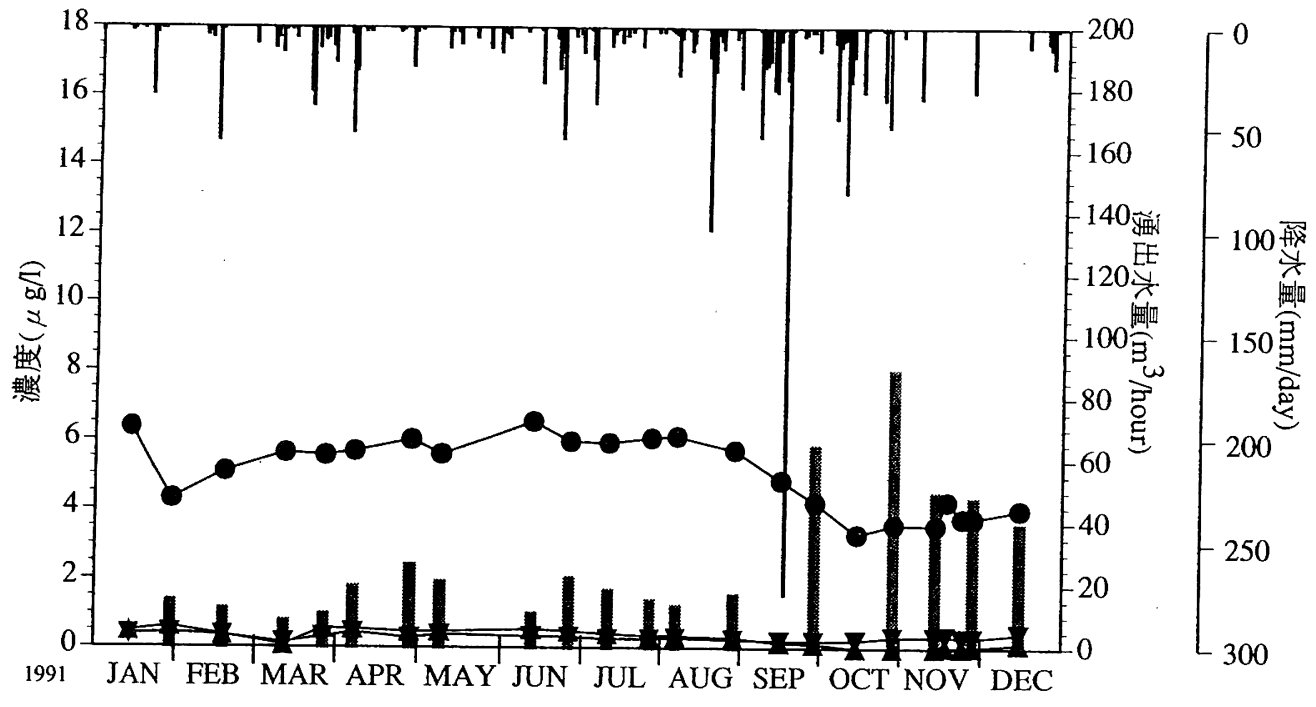

查の結果も加えて TCE と MCの関係を表わすグ ラフを作成した(但し、1987、1988年は N0w のみ)。 その結果は図 3 に示寸関係となり、図のように 4 つの湧水を東側 ( $\mathrm{NOk} 、 \mathrm{NOe}$ ) と西側 ( $\mathrm{N} 0 \mathrm{w} 、 \mathrm{NOm}$ ) の 2 グループに分けることが出来た。それぞれの 相関係数は N0k と N0eが $0.91(\mathrm{n}=58) 、 \mathrm{~N} 0 \mathrm{w}$ と $\mathrm{NOm}$ が $0.79(=156)$ と比較的高い相関が得られた。
以上の結果から、先に述べたように 4 地点の湧 水のうち東側の $\mathrm{N} 0 \mathrm{k} 、 \mathrm{~N} 0 \mathrm{e}$ と西側の $\mathrm{N} 0 \mathrm{w} 、 \mathrm{~N} 0 \mathrm{~m}$ と では湧水の污染状況が異なっており、真姿の池湧 水群付近には地下水の分水界があると推定され た。

（1）で述べたように NOe に比べNOk の TCE 濃度 が大きく、また両地点の TCE 濃度の月変化の様 
(d)
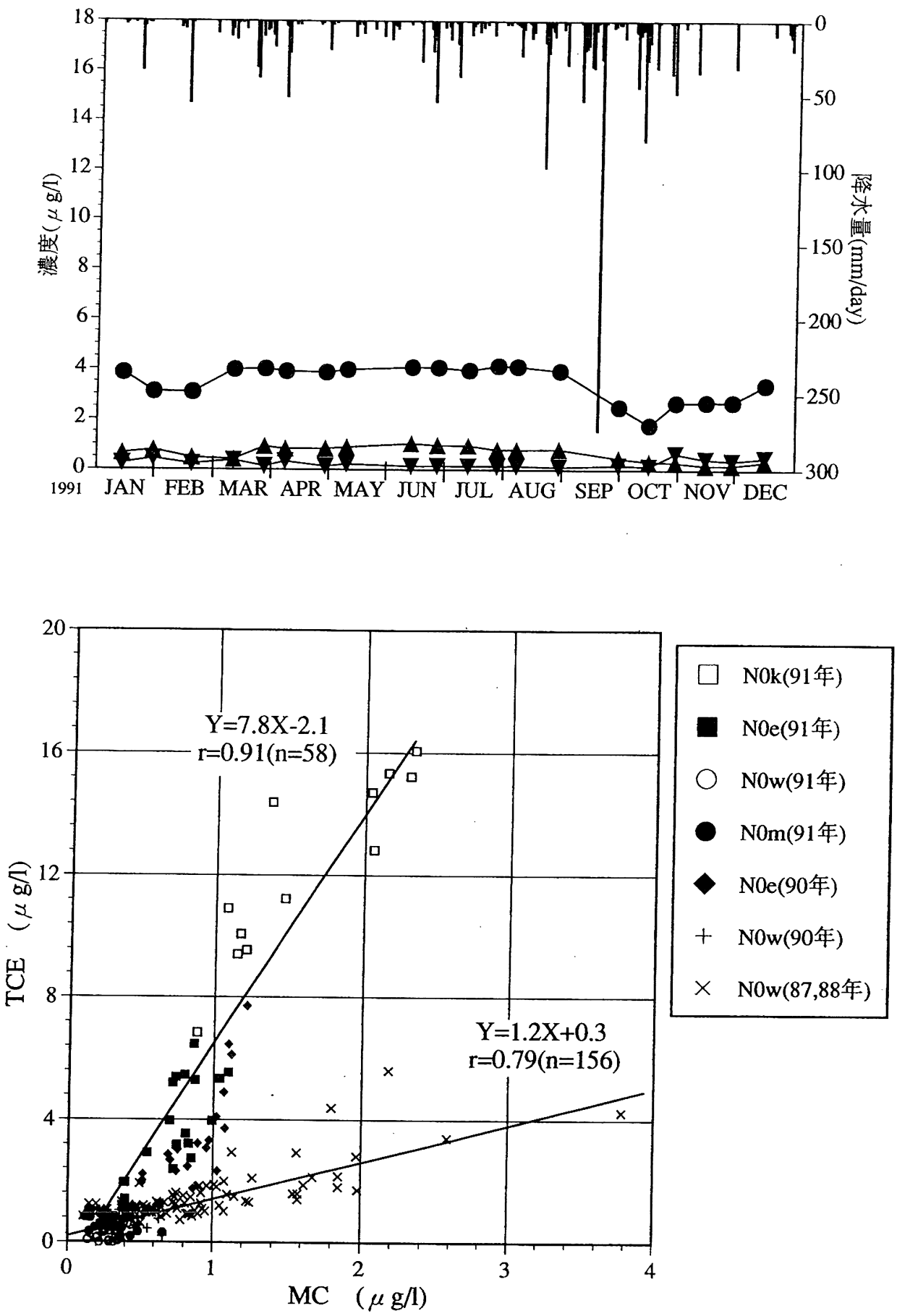

図 3 湧水中の TCE と MC の関係

(Relation of TCE and MC at spring waters)

注) 1987、1988データ 加藤、小倉 (1990)

1990データ 平野(1991) 
子が類似していることから NOk 方向から N0e 方 向へ向かう地下水の流れがあり、その流れにより TCEが運ばれているのではないかと推定された (図 2-a、b)。さらに N0kよりも N0e の方が濃 度が低いのはTCEによる污染の少ない地下水が NOe へ供給されることにより揮発性有機塩素化合 物が希釈されている可能性を示唆していると考え られた。

NOe においては降水量の増加と共にTCEと

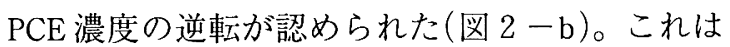
NOw と NOe では通常は地下水の流れが異なって いるが、台風時には多量の降水により $\mathrm{N} 0 \mathrm{w}$ 一供 給される地下水の水位が上昇し、 $\mathrm{NOe}$ 側へ流れ込 んだためと推定された。

\section{( 3 ) 湧水と武蔵野面上の浅層地下水の揮発} 性有機塩素化合物の関連性

湧水中の揮発性有機塩素化合物濃度および地下 水の流れが真姿の池湧水群を中心として東西で異 なることが推定された。そこで 4 つの湧水周辺の 武蔵野面での揮発性有機塩素化合物による污染状 況を知るため、武蔵野面の浅層地下水の揮発性有 機塩素化合物の調查を行った。調査対象には普段 揚水している井戸が最適であるが、本調査地域で は住宅地が少ないこと、地下水位の低下や水質污 染などにより常時使用している井戸が減少してい るため調査には主として井戸跡や水位観測孔を用 いた(図 1 )。

水質調査の結果を表 2 に示したが、武蔵野面上 の井戸では TCE 濃度は平均して非常に低く、14 地点中 2 地点においてのみ TCE 濃度が優先して いた。PCEについては N0w と同程度の濃度を示 した井戸が認められた。地図上で調査地点の位置 関係を見ると真姿の池湧水群を中心として TCE 濃度が高い地点と PCE 濃度が高い地点とに分け ることができた(図 4 )。このことから、武蔵野面 において真姿の池湧水群より西方向から PCE、 東方向から TCEの混入があったと推定されるが、 これ等の污染源を特定するには至らなかった。

\section{5. まとめ}

真姿の池湧水群を中心とした小集水域において
表 2 武藏野台地の浅層地下水中の揮発性有機塩素化 合物濃度

(Concentrations of Volatile Organochlorine Compounds in the shallow ground water at Musashino Upland)

\begin{tabular}{|c|c|c|c|}
\hline & MC & TCE & PCE \\
\hline 1 & 0.38 & 8.33 & 0.34 \\
\hline 2 & 0.40 & N.D. & 0.61 \\
\hline 3 & 0.28 & 0.25 & 3.96 \\
\hline 4 & 0.10 & N.D. & 0.78 \\
\hline 5 & 0.40 & N.D. & 0.35 \\
\hline 6 & 0.40 & 0.51 & 6.29 \\
\hline 7 & 0.15 & N.D. & 2.62 \\
\hline 8 & 0.23 & 0.08 & 3.50 \\
\hline 9 & 0.40 & N.D. & 0.24 \\
\hline 10 & 0.25 & 0.30 & 4.10 \\
\hline 11 & 0.30 & 0.11 & 3.14 \\
\hline 12 & 0.50 & N.D. & 0.25 \\
\hline 13 & 0.33 & N.D. & 0.26 \\
\hline 14 & 0.41 & 0.14 & 2.69 \\
\hline
\end{tabular}

単位 $\mu \mathrm{g} / 1$

（N.D.-検出限界以下）

は MC 濃度と TCE 濃度との間に正の相関が認め

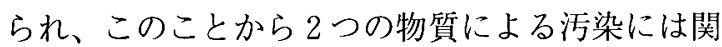
係があることがわかった。

湧水の揮発性有機塩素化合物濃度の関係から、 真姿の池湧水群では湧出口ごとに水質が異なって おり、真姿の池湧水群は異なる地下水流れで涵養 されていることが推定された。

いくつかの揮発性有機塩素化合物について各々 の濃度を測定し、相互の関連性を検討することは 比較的狭い範囲での地下水の流れを推定するのに 有効であると思われる。

\section{謝辞}

本研究を行うにあたり、御協力いただきました 東京農工大学農学部環境保護学科土畩水界環境学 講座の皆様に感謝いたします。また、通産省工学 技術院の上田真吾氏、東京都の加藤寛久氏、平野 晃章氏には本研究を行うにあたり貴重なデー夕お 


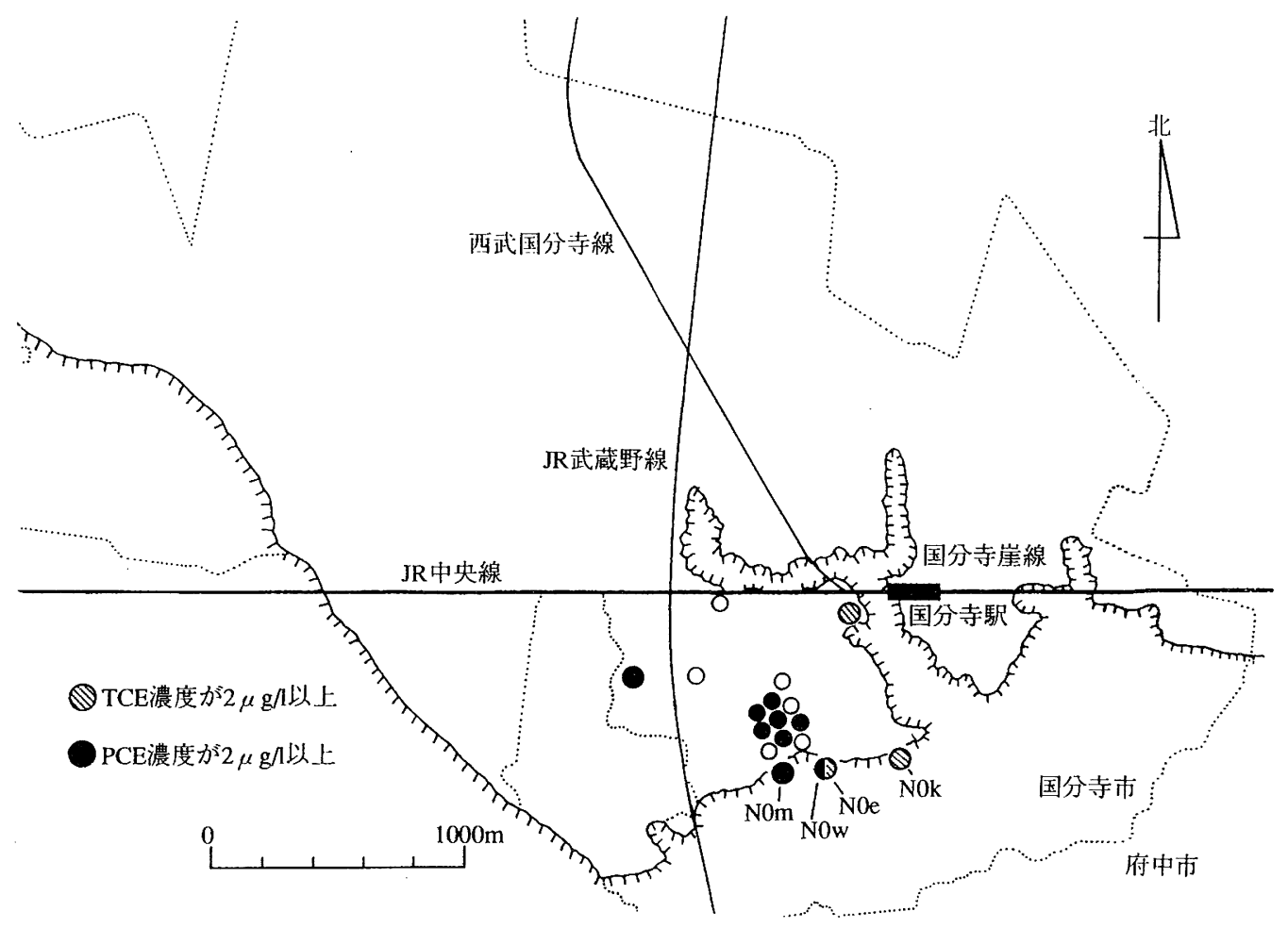

图 4 湧水および浅層地下水中の揮発性有機塩素化合物の分布

(Distribution of Volatile Organochlorine Compounds in springs and shallow groundwaters)

よび御意見をいただきましたことを感謝いたしま す。最後に本論文の構成にあたり、助言をいただ きました大成建設株式会社の藤原靖氏にお礼申し 上げます。

\section{参 考 文 献}

貝塚爽平 (1979)：東京都地学のガイド 東京都地学の ガイド編集委員会編

加藤寛久、小倉紀雄(1990)：東宗北多摩地区の湧水、 抢よび深井戸水中の揮発性有機塩素系化合物 水質 污濁研究 13-7、449 455
気象庁 $(1991)$ : 東京管区気象月報 1 月 -12 月

国立環境研究所(1991)：土壤および地下水圈における 有害化学物質の挙動に関する研究 国立環境研究所 特別研究報告 $5 \mathrm{p}$

平野晃章(1991)：武蔵野台地浅層地下水の動態と水質 特性 東宗農工大学1990年度卒業論文

平野晃章、小倉紀雄 (1992)：水質変動からみた湧泉の 湧出機構推定の試み 水利科学 $36-2 、 63 \sim 79$

Rivett.M.O., Lerner.D.N., Lloyd.J.W. and Clark. L (1990): Organic contamination of the Birmingham aquifer, Journal of Hydrology, 113, 307-323

（受付：1994年 6 月30日、受理：1994年10月20日） 